\title{
Decomposition of senescent blades of the seagrass Halodule wrightii in a subtropical lagoon
}

\author{
Stephen Opsahl, Ronald Benner \\ University of Texas at Austin, Marine Science Institute, Port Aransas, Texas 78373-1267, USA
}

\begin{abstract}
Senescent blades from the seagrass Halodule wrightii Aschers were suspended in the water column of Laguna Madre (Texas, USA) for a period of $419 \mathrm{~d}$, representing the longest seagrass decomposition study to date. The initial stage of decomposition was characterized by a rapid loss of organic matter ( $36 \%$ in $24 \mathrm{~d}$ ) attributed to leaching. A total of $76 \%$ of the organic matter from seagrass tissues was lost by the end of the decomposition period. Of the major bulk constituents measured, neutral sugars were most abundant and accounted for $23 \%$ of the ash-free dry wt of the initial senescent material. A complete and early loss of the cyclitol, myo-inositol, a reduction in glucose yields, and a relative enrichment in mannose were the most dynamic features of the neutral sugar fraction. An overall stability series: mannose $>$ fucose $>$ arabinose $\approx$ rhamnose $\approx$ galactose $=$ xylose $>$ glucose, reflects patterns of selective degradation of the polymers from which these sugars are derived. Soluble and ester-bound phenolic acids were lost from tissues at relatively high rates. Susceptibility of individual phenolic acids to removal from bulk tissue upon treatment with weak base correlated well to initial losses in the field. Early changes in total $\mathrm{CuO}$ oxidation phenol yields from $H$. wrightii were caused primarily by the relatively rapid loss of soluble and ester-bound phenolic acids. Therefore, we took a new approach to quantify lignin-derived phenols by subtracting soluble and ester-bound phenols from total $\mathrm{CuO}$ oxidation yields. When these losses were taken into account, lignin-derived phenol yields were similar from freshly senescent and highly degraded detritus. Cutin, although initially selectively preserved relative to bulk tissue, was also found at near initial yields in the highly degraded detritus. Overall, the distribution of polymeric constituents (cellulose, hemicellulose, lignin and cutin) was similar in freshly senescent and highly degraded tissues suggesting that the compounds which comprise the ultrastructure of $H$. wrightil are degraded at similar rates. Photobleached $H$. wrightii blades were characterized by a much higher neutral sugar content, similar levels of cutin acids and a nearly complete absence of phenols compared to freshly senescent tissue. Photobleaching appears to be an important degradative mechanism which yields a polysaccharide-rich detritus that is devoid of the lignin signature characteristic of vascular plant tissues.
\end{abstract}

\section{INTRODUCTION}

Seagrasses are major primary producers in many temperate and tropical coastal environments, and the fate of seagrass biomass is an integral component of the complex flow of carbon and energy in these ecosystems. Upon senescence, carbon losses due to leaching contribute to labile pools of dissolved organic matter (Godshalk \& Wetzel 1978, Rublee \& Roman 1982) leading to elevated levels of microbial production (Benner \& Hodson 1985, Benner et al. 1986b, Blum \& Mills 1991) which in turn support detrital food webs (Robertson et al. 1982, Findlay et al. 1986, Peduzzi \& Herndl 1991). Structural constituents, such as lignin, cellulose and hemicellulose, degrade more slowly and comprise a long-term reservoir of particulate organic matter which also contributes to higher trophic levels (Benner et al. 1984, Valiela et al. 1985, Benner et al. 1988). Selective losses throughout decomposition alter the chemical composition of tissues and thus the availability of individual constituents of the detritus to the microbial community.

Carbohydrates are major components of vascular plant tissues. Within the total carbohydrate pool, neutral sugars are important constituents since the majority of monosaccharides which form the structural polymers cellulose, hemicellulose and pectin are included in this class. Cyclitols, also neutral sugars, are important membrane constituents and intermediates in cellular metabolism (Loewus \& Dickinson 1981), and 
have been shown to be abundant in seagrasses (Drew 1980). Taken together, these neutral sugars are likely to be the predominant form of carbohydrate in seagrasses and therefore would comprise the bulk of carbon flux from decomposing seagrass tissue. Little information regarding the neutral sugar content of seagrasses or the reactivity of specific carbohydrates during decomposition is presently available.

Phenolic compounds are common constituents of vascular plants and may be separated into 3 operationally-defined classes: soluble, ester-bound and lignin-derived (Wilson et al. 1986, this study). Soluble phenolic acids have been shown to be abundant in a variety of seagrasses (Zapata \& McMillan 1979, Buchsbaum et al. 1991) and seagrass extracts rich in soluble phenols have been found to inhibit the growth of bacteria and algae (Harrison \& Chan 1980). Esterbound phenols may be linked to lignin (Higuchi et al. 1967) or cell-wall carbohydrate (Hartley 1973), and are degraded at considerably lower rates than soluble phenols (Wilson et al. 1986). Lignin is a structural polymer of phenylpropane subunits which are linked by carbon-carbon and ether bonds. Lignin is a unique constituent of vascular plants (Sarkanen \& Ludwig 1971) that is typically found to be resistant to microbial degradation (Benner et al. 1986b). Therefore, lignin can be useful as a biomarker for vascular plant-derived organic matter in heterogeneous samples such as sediments, and dissolved organic matter (Hedges \& Parker 1976, Meyers-Schulte \& Hedges 1986, Hamilton \& Hedges 1988). By making these distinctions between individual pools of phenolic compounds, associated relative reactivities and degradation rates can be investigated.

Cutin is an important component of the protective outer covering (cuticle) of vascular plant herbaceous tissues (Martin \& Juniper 1970). Taxonomic distinctions based on characteristic distributions of individual cutin-derived hydroxy acids have been established (Holloway 1982, Goni \& Hedges 1990b) so that these compounds may serve as specific geochemical indicators of particular plant types. The degradation of cutin acids in conifer needles has been studied (Goni \& Hedges 1990c), and as a group, cutin acids were found to be more reactive than either the lignin or carbohydrate fractions. The reactivity of individual cutin acids was also shown to vary. In order to determine the relative stability of seagrass-derived cutin, chemical changes which take place during the decomposition of seagrass detritus need to be evaluated.

In the present study, we investigated the short-and long-term decomposition of senescent above-ground Halodule wrightii Aschers tissues in the Laguna Madre, Texas, USA. Increasing evidence, such as stable carbon isotope analyses, supports the hypo- thesis that seagrass-derived carbon is transferred to higher trophic levels in this and other systems (Fry \& Parker 1979, Stevenson 1988) via a microbial food web (Chin-Leo \& Benner 1991). To evaluate this transfer of carbon more closely, we measured changes in the aldose, cyclitol, soluble and ester-bound phenols, and lignin- and cutin-derived cupric oxide oxidation products during the decomposition of $H$. wrightii. The duration of this experiment ( $419 \mathrm{~d}$ ) and the analytical techniques used to measure chemical changes make this study unique in the area of seagrass decomposition. Trends are discussed in terms of the chemical composition of seagrass detritus and biomarker applications.

\section{MATERIALS AND METHODS}

Site description. Seagrass decomposition experiments were conducted in the Laguna Madre, which spans approximately $200 \mathrm{~km}$ from Corpus Christi, Texas, to the Mexican border. The lagoon covers a total area of over $1100 \mathrm{~km}^{2}$ and is separated from the Gulf of Mexico by Padre Island. This system is unusual in that high levels of sunlight and evaporation, low rainfall, minimal freshwater inflow and distant tidal passes all contribute to hypersaline conditions characteristic of this lagoon throughout much of the year. The average water depth in the Laguna Madre is about $1 \mathrm{~m}$ and there is a very limited tidal range, however, occasional inundations such as hurricanes, completely flush the system with freshwater.

The vast majority of the lagoon bottom is covered by seagrasses with Halodule wrightii being the predominant species. With the exception of ducks which feed on $H$. wrightii roots and rhizomes during the winter, grazers have a minimal impact on the seagrass biomass. Typical salinities throughout the duration of this study ranged from 33 to $55 \%$ and water temperatures ranged from 0 to $30^{\circ} \mathrm{C}$.

Decomposition experiment. Samples of green and senescent seagrass material were collected during September 1988. Attached blades of Halodule wrightii which were entirely green in color were collected for a representation of fresh, actively growing tissue. Attached blades which were green with some areas of yellowish-brown color were picked to represent senescent tissue. This senescent tissue was chosen as the initial starting material in the litter bag experiment.

Large quantities of decaying seagrass are pushed onto the shoreline during periods of strong wind and remain out of the water for long periods of time. This portion of the shoreline is typically dry, although high tides and rain will occasionally saturate this area with water. A sample of dried seagrass blades which was 
entirely white in color (photobleached) was collected from the supralittoral portion of the shoreline adjacent to the study site. This material is subjected to high levels of sunlight which is not attenuated by the water column. An additional sample of brown seagrass detritus was collected directly underneath the photobleached layer. Photobleached material is present along virtually the entire perimeter of the Laguna Madre.

Immediately after collection, all seagrass blades were rinsed in distilled water to remove salt. Separation of epiphytic algae from associated seagrass tissue was not a concern in this study since the high salinities restrict growth of epiphytes. The effects of drying leaf litter before experimental manipulations has been a topic of concern in decomposition studies. In the Laguna Madre, large wracks of seagrass detritus are frequently pushed out of the water during which time they undergo considerable drying at temperatures in excess of $40^{\circ} \mathrm{C}$. The extent to which seagrass detritus undergoes submergence and drying in its natural setting has not yet been determined. In this study, a drying temperature of $45^{\circ} \mathrm{C}$ was chosen to minimize potential changes in chemical composition yet permit accurate mass loss measurements, although we do recognize that rates of decomposition, primarily during the leaching phase, may be enhanced as a result of drying (Harrison \& Mann 1975).

Litter bags. Litter bags measuring $43 \times 33 \mathrm{~cm}$ were constructed out of $202 \mu \mathrm{m}$ Nitex mesh (Tetko, Inc.). Senescent seagrass blades (10 g) were placed in each litter bag and the bags were sewn shut with nylon thread. Bags were spaced $30 \mathrm{~cm}$ apart and suspended in the water column from nylon rope which was secured to PVC pipes. Bags were attached to the nylon rope using cable ties. The design was such that the litter bags would be suspended in the water column above the sediment but would remain submerged even during the lowest tides. Bags were placed in the field on October 28, 1988 and 2 bags were harvested at approximately monthly intervals.

After collection, bags were transported to the laboratory where they were rinsed in distilled water. The contents of the bags were emptied into a clean glass dish filled with distilled water, which facilitated careful separation of recognizable seagrass detritus from other material. Most of the extraneous material consisted of small bivalves and molluscs which likely entered during larval or juvenile stages and matured inside the bags. Once rinsed and separated, the seagrass detritus was placed in a drying oven at $45^{\circ} \mathrm{C}$ for $48 \mathrm{~h}$ and the contents were then weighed. The contents of the bags were not combined and all chemical analyses were made on individual bags. Duplicate sub-samples from each bag were combusted at $550^{\circ} \mathrm{C}$ for $6 \mathrm{~h}$ so that all chemical analyses could be evaluated on an ash-free dry wt (AFDW) basis.

Neutral sugar determinations. Neutral sugars were measured by the method of Cowie \& Hedges (1984a). A $20 \mathrm{mg}$ sample was pre-treated with $12 \mathrm{M} \mathrm{H}_{2} \mathrm{SO}_{4}$ for $2 \mathrm{~h}$, diluted to $1.2 \mathrm{M}$ and hydrolyzed $3 \mathrm{~h}$ at $100^{\circ} \mathrm{C}$. After hydrolysis, adonitol was added to the mixture as an internal standard. The sample was neutralized with $\mathrm{Ba}(\mathrm{OH})_{2}$, deionized in a mixed bed of cation/anion exchange resins, dried in a Savant Speed-Vac centrifugal evaporating system and resuspended in pyridine. Sorbitol was added to the sample as an absolute recovery standard. Next, an equal volume of $0.4 \%$ (w/v) $\mathrm{LiClO}_{4}$ in pyridine was added and the mixture then held at $60^{\circ} \mathrm{C}$ for a $48 \mathrm{~h}$ equilibration period. The mixture was derivatized by adding Sylon BFT (Supelco) and held at $60^{\circ} \mathrm{C}$ for an additional $10 \mathrm{~min}$. The resulting mixture of trimethylsilyl derivatives was separated on a Hewellet Packard 5890 gas chromatograph using simultaneous analyses on non-polar and polar capillary columns (DB-1 and DB-1701, J\&W Scientific). The column temperature program began at $140^{\circ} \mathrm{C}$, held for $4 \mathrm{~min}$, increased to $270^{\circ} \mathrm{C}$ at $6^{\circ} \mathrm{C} \mathrm{min}^{-1}$, and then held for an additional $4 \mathrm{~min}$. The DB-1 column was used for most quantifications but occasional co-elutions were detected by comparison with the DB-1701 column and these sugars were quantified using DB-1701 data. At equilibrium, each sugar may have from 1 to 5 detectable isomeric peaks and the largest of these which was clearly resolved was used for quantification. Lyxose and ribose were nearly absent in all tissues, producing small peaks on the gas chromatograph which could not be identified or quantified reliably, and therefore were considered trace constituents.

Individual sugar monomers produced during the hydrolysis of polymeric carbohydrate, become hydrated at the glycosidic linkage during cleavage. For final calculation of neutral sugar yields, this weight gain is subtracted from total yields, reducing them by ca $10 \%$ depending on the molecular weight of the sugar monomer. Neutral sugar yields have not been adjusted to account for incomplete hydrolysis of polymers. For example, under optimal conditions, hydrolysis of purified cellulose yielded an $80 \%$ recovery of glucose (Cowie \& Hedges 1984a).

Sample mean deviation is reported to be 5 to $10 \%$ for individual sugars but typically falls below $5 \%$ for more abundant sugars (Cowie \& Hedges 1984a). In this study, we analyzed each bag twice for neutral sugar content. We then calculated sample mean deviations for replicate litter bags harvested at each time point. Average percent mean deviations for each sugar calculated from the time series ranged from 4 to $13 \%$. 
Soluble phenolic acids. Numerous monomeric and polymeric aromatic constituents are released upon extraction in $80 \%$ methanol (Van Sumere 1989). This extraction releases free phenolics but leaves those bound by ester-linkages intact (Van Sumere 1989). In the present study, several important monomeric phenols released by methanol extraction were identified and quantified. Vanillic, syringic, p-coumaric and ferulic are among the most abundant phenolic acids found in seagrasses, although others have been identified (Zapata \& McMillan 1979). We have focused on these phenolic acids in order to make comparisons with these same compounds which are also found in ester-bound form and are produced from lignin during CuO oxidation (see below).

To measure soluble phenolic acids, a $200 \mathrm{mg}$ sample of dried plant material was extracted 3 times in $10 \mathrm{ml}$ of $80 \%$ methanol at $80^{\circ} \mathrm{C}$ for $10 \mathrm{~min}$. Ethylvanillin was added as an internal standard prior to the initial methanol extraction. The extracts were combined and dried by evaporation under nitrogen. Extracts were then resuspended in water and acidified to $\mathrm{pH} 1$ with $6 \mathrm{~N} \mathrm{HCl}$. Subsequent ether extraction and analysis for individual phenols proceeded as described below for lignin-derived phenols.

Ester-bound phenols. A relatively mild hydrolysis with weak base was used to release soluble and esterbound phenols (Whitehead et al. 1981). Ester-bound phenols are defined herein as those phenols which are released upon mild base hydrolysis minus the soluble phenols which are extracted in $80 \%$ methanol. Recovery and determination of ester-bound phenols proceeded as follows: a $200 \mathrm{mg}$ sample of dried plant material was placed in a $50 \mathrm{ml}$ screw-cap tube with $16 \mathrm{ml}$ of $1 \mathrm{~N} \mathrm{NaOH}$. This mixture was then spiked with the internal standard ethylvanillin. The sample was reacted for $20 \mathrm{~h}$ at room temperature with a magnetic stir bar for mixing. At the end of the hydrolysis, the samples were filtered through pre-combusted Whatman GF/F filters. The hydrolysate was acidified to $\mathrm{pH} 1$ with $6 \mathrm{~N} \mathrm{HCl}$. Subsequent ether extraction and analysis for individual phenols proceeded as described below for lignin-derived phenols. The yields of soluble phenols were always a small $(<10 \%)$ fraction of the total yields of phenols released upon mild base hydrolysis.

Lignin-derived phenols. A standard method for the determination of lignin-derived phenols was used to oxidize samples in an alkaline solution with $\mathrm{CuO}$ (Hedges \& Mann 1979). We used the procedure described by Hedges \& Ertel (1982) with a few minor modifications. A $40 \mathrm{mg}$ sample was reacted with $\mathrm{CuO}$ in $2 \mathrm{~N} \mathrm{NaOH}$ in stainless steel mini-bombs at an internal reaction temperature of $155^{\circ} \mathrm{C}$ for $3 \mathrm{~h}$ (Goni \& Hedges 1992). Ethylvanillin (25 to $100 \mu \mathrm{g}$ ) was added to the sample after bombing as an internal standard. The sample was rinsed out of the mini-bomb with $20 \mathrm{ml}$ of $1 \mathrm{~N} \mathrm{NaOH}$, centrifuged and decanted. This rinsing procedure was repeated 2 times and the combined extracts were acidified to $\mathrm{pH} 1$ with $6 \mathrm{~N} \mathrm{HCl}$. The mixture was extracted 3 times with freshly distilled ether and dried under nitrogen. The dried sample was resuspended in pyridine from which a subsample was transferred to another vial. This subsample was mixed with an equal volume of Sylon BFT (Supelco Inc.) and heated at $60^{\circ} \mathrm{C}$ in a heating block for $10 \mathrm{~min}$. The resulting trimethylsilyl derivatives were separated using the same gas chromatograph and capillary columns used for neutral sugars.

Concentrations for most compounds agreed very well between columns $( \pm 10 \%)$ with the exception of $p$ hydroxybenzaldehyde and ferulic acid which have been previously reported to have co-eluting compounds on the DB-1 column (Hamilton \& Hedges 1988). Each litter bag was analyzed for lignin-derived phenols. Sample mean deviations were calculated from replicate litter bags harvested at each time point. The average percent mean deviation for individual phenols throughout the time series ranged from 10 to $20 \%$. Peak identification for some of the phenols was sometimes difficult in the more highly degraded samples because they occurred in low concentrations. To verify identification of these peaks, some samples were co-injected with a small amount of the standard solution. Elevated peak areas for perfectly co-eluting peaks on both columns was accepted as a means of positive identification for co-injected samples. For positive identification of the lignin-derived phenols (which were low in concentration relative to most other vascular plants), the initial senescent starting material was analyzed by gas chromatography/mass spectrometry (GC/MS), which verified the presence of all 11 index phenols produced during the $\mathrm{CuO}$ oxidation of lignin. In order to quantify those phenols derived exclusively from lignin, they must be distinguished from soluble and ester-bound phenols. We herein define lignin-derived phenols as those phenols produced from the CuO oxidation of whole tissue minus phenols released after mild base hydrolysis (see 'Results and Discussion')

Cutin. Traditional methods for analysis of cutin (Eglington \& Hunneman 1968, Holloway 1973, Kolattukudy \& Espelie 1985) yield 2 predominant families of hydroxylated fatty acids $\left(\mathrm{C}_{16}\right.$ and $\mathrm{C}_{18}$ groups). Goni \& Hedges (1990a) have shown that these cutin acids are present, both qualitatively and quantitatively, as reaction products in the ether extracts from the alkaline cupric oxide oxidation used for analysis of ligninderived phenols. These cutin-derived hydroxy acids eluted between 30 and $50 \mathrm{~min}$. Co-elution of cutin 
acids was a problem on the DB-1701 column, therefore all measurements of these compounds were made using the DB-1 column. Commercial standards are not available for most of these compounds. Therefore, relative retention times were related to a series of $C_{13}$ to $\mathrm{C}_{26}$ saturated fatty acids as described by Goni \& Hedges (1990a). All concentrations for cutin-derived compounds for which we had no standards were calculated using the response factor of ethylvanillin. Additionally, the initial starting material was analyzed by GC/MS to confirm the identity of the 4 cutin acids measured. The abundance of individual isomers of 2 of the $C_{16}$ hydroxylated fatty acids $[(8,9$ or 10$)$ dihydroxyhexadecanoic acid $\left(x, \omega-C_{16}\right)$ and $(7$ or 8$)$ hydroxyhexadecane-1,16-dioic acid $\left.\left(x-C_{16} D A\right)\right]$ were not determined for the time series, therefore only the sum total which elutes as a single peak during gas chromatography was reported for each of these compounds. Average percent mean deviations were calculated as described for lignin-derived phenols and ranged from 12 to $16 \%$ for the individual cutin-derived hydroxy acids.

\section{RESULTS AND DISCUSSION}

\section{Weight loss}

Decomposition, in this study, refers to the loss of dissolved and particulate organic matter from the original starting material which was placed in the litter bags. Losses include complete mineralization, leaching of dissolved organic constituents and loss of small particulate matter $(<202 \mu \mathrm{m})$. Halodule wrightii lost $35.5 \%$ of its initial weight (AFDW) after only $24 \mathrm{~d}$ in the field (Fig. 1), primarily due to leaching which has

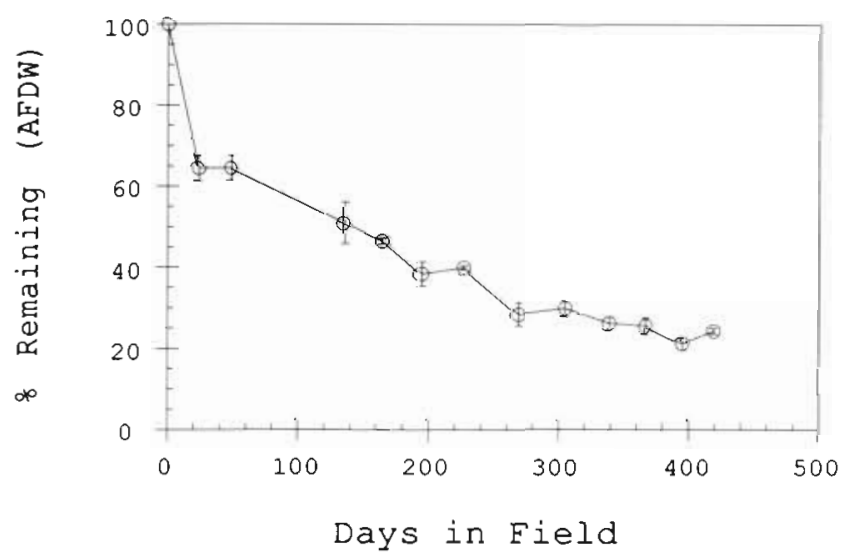

Fig. 1. Halodule wrightii. Weight loss expressed as a percentage of ash-free dry weight (AFDW) remaining. Each symbol represents the average weight loss for replicate litter bags Error bars depict sample mean deviations been shown to release more soluble constituents from the particulate detritus of aquatic macrophytes (Godshalk \& Wetzel 1978, Benner \& Hodson 1985, Valiela et al. 1985). A total of $76 \%$ of the organic mass was lost after 419 d providing a decay rate of $0.18 \% \mathrm{~d}^{-1}$, which falls within the lower range of decay rates based on linear models reported for a variety of seagrasses summarized in a review by Harrison (1989). However, this survey includes decomposition data from studies which vary in length, seagrass species, initial starting material, litter bag mesh size and field conditions making any direct comparisons of decay rates difficult.

\section{Neutral sugars}

Yields of the individual neutral sugars from all samples are presented in Table 1. Glucose was the most abundant neutral sugar accounting for $176.4 \mathrm{mg} \mathrm{g}^{-1}$ AFDW and $74 \%$ of the total neutral sugar yield in freshly senescent tissues. Corresponding yields of other neutral sugars ranged from $3.3 \mathrm{mg} \mathrm{g}^{-1}$ in the case of myo-inositol to $17.3 \mathrm{mg} \mathrm{g}^{-1}$ for xylose. Myo-inositol was the only cyclitol recovered from Halodule wrightii which agrees with results from a study on the soluble carbohydrate composition of seagrasses by Drew (1980). Total neutral sugar yields accounted for $24 \%$ of the total organic mass of freshly senescent $H$. wrightii blades.

Large changes in distributional patterns of individual sugars were evident during the first $24 \mathrm{~d}$ of decomposition. Like conifer needles (Hedges \& Weliky 1989) and mangrove leaves (Benner et al. 1990a), Halodule wrightii lost all myo-inositol during the earliest stages of decomposition, and this cyclitol was the most labile constituent measured. Losses of individual sugars during the first $24 \mathrm{~d}$ of decomposition ranged from $21 \%$ in the case of glucose to $54 \%$ for mannose. Approximately $26 \%$ of the total initial neutral sugar pool was lost during this time.

Abundance patterns for neutral sugars during the latter portion of the litter-bag study included relative enrichment in mannose, arabinose and fucose, which accounted for $8.6,6.8$ and $3.0 \mathrm{mg} \mathrm{g}^{-1}$ AFDW of senescent tissue and $17.0,8.1$ and $4.3 \mathrm{mg} \mathrm{g}^{-1}$ AFDW after $419 \mathrm{~d}$ of decomposition. Rhamnose and xylose yields demonstrated little net change during the study. Glucose underwent a major reduction in yields from 176.4 to $111.2 \mathrm{mg} \mathrm{g}^{-1}$ AFDW. Xylose was the only sugar which maintained a fairly constant proportion of the total neutral sugar content $(8.0 \pm 0.4 \%)$. Yields of galactose varied starting with $12.2 \mathrm{mg} \mathrm{g}^{-1}$ AFDW in senescent tissue, which decreased rapidly to $7.5 \mathrm{mg} \mathrm{g}^{-1}$ AFDW after $49 \mathrm{~d}$ and then consistently increased to $12.1 \mathrm{mg} \mathrm{g}^{-1}$ AFDW by the end of the study. Total neu- 
Table 1. Halodule wrightii. Neutral sugar yields (mg carbohydrate $g^{-1}$ AFDW) for green, senescent, decomposing and photobleached seagrass blades. Deviation: average percent mean deviation for decomposing samples. GLU: glucose; GAL: galactose; MAN: mannose; RHA: rhamnose; FUC: fucose; XYL: xylose; ARA: arabinose; MYO: myo-inositol; Total: total yield of neutral sugars

\begin{tabular}{|lccccccccc|}
\hline Sample & GLU & GAL & MAN & RHA & FUC & XYL & ARA & MYO & Total \\
\hline Green & 169.9 & 11.1 & 6.7 & 7.5 & 2.5 & 17.1 & 6.1 & 7.0 & 227.9 \\
Senescent & 176.4 & 12.2 & 8.6 & 9.6 & 3.0 & 17.3 & 6.8 & 3.3 & 237.2 \\
Decomposing (d) & & & & & & & & & \\
24 & 213.7 & 9.0 & 6.1 & 10.5 & 2.8 & 20.9 & 7.0 & 0.0 & 270.0 \\
49 & 184.7 & 7.5 & 7.9 & 10.7 & 2.7 & 18.3 & 6.5 & 0.0 & 238.3 \\
136 & 180.4 & 8.6 & 7.2 & 10.5 & 2.4 & 19.2 & 7.8 & 0.0 & 236.1 \\
166 & 159.7 & 8.5 & 7.9 & 11.6 & 2.9 & 16.2 & 8.0 & 0.0 & 214.7 \\
195 & 138.8 & 8.7 & 8.0 & 12.1 & 2.9 & 16.6 & 8.0 & 0.0 & 195.1 \\
227 & 141.6 & 8.0 & 8.1 & 11.9 & 2.7 & 16.0 & 8.2 & 0.0 & 196.5 \\
269 & 161.6 & 9.5 & 9.3 & 12.7 & 3.4 & 19.1 & 8.8 & 0.0 & 224.4 \\
305 & 142.4 & 10.0 & 14.5 & 11.6 & 3.8 & 16.4 & 8.1 & 0.0 & 206.8 \\
339 & 117.6 & 10.4 & 18.3 & 10.5 & 4.5 & 14.4 & 7.6 & 0.0 & 183.3 \\
367 & 136.2 & 9.8 & 13.2 & 11.1 & 3.7 & 16.3 & 7.9 & 0.0 & 198.2 \\
395 & 130.9 & 10.8 & 15.3 & 11.2 & 4.5 & 17.1 & 8.2 & 0.0 & 198.0 \\
419 & 111.2 & 12.1 & 17.0 & 10.1 & 4.3 & 15.2 & 8.1 & 0.0 & 178.0 \\
Photobleached & $(4 \%)$ & $(6 \%)$ & $(13 \%)$ & $(5 \%)$ & $(7 \%)$ & $(5 \%)$ & $(4 \%)$ & \\
\end{tabular}

tral sugar yields varied from $237.2 \mathrm{mg} \mathrm{g}^{-1}$ AFDW in senescent tissues, to $178.0 \mathrm{mg} \mathrm{g}^{-1}$ AFDW by the end of the study, and this trend in total neutral sugar yield was essentially determined by changes in glucose abundance.

The neutral sugar profile from photobleached detritus varied considerably from senescent and highly degraded submerged tissues with respect to individual sugars and total recoveries (Table 1 ). The yield of glucose (321.5 $\mathrm{mg} \mathrm{g}^{-1}$ AFDW) was 1.8 times that of senescent tissue and 2.9 times that of highly decomposed submerged material. Glucose accounted for $82 \%$ of the total neutral sugar content and $32 \%$ of the total organic mass of this detritus. The xylose yield was $30.2 \mathrm{mg} \mathrm{g}^{-1}$ AFDW, 1.8 times that of senescent tissue. This detritus was also slightly enriched in rhamnose, slightly depleted in galactose and completely depleted in myo-inositol relative to undegraded material. Overall, $39 \%$ of the total organic mass of bleached detritus could be accounted for as neutral sugars compared to 18 to $27 \%$ for the submerged blades in the litter bag study.

The $\mathrm{H}_{2} \mathrm{SO}_{4}$ pretreatment is necessary in order to efficiently hydrolyze cellulose. An additional analysis, in which the $12 \mathrm{M} \mathrm{H}_{2} \mathrm{SO}_{4}$ pretreatment was excluded, was made on senescent Halodule wrightii. By excluding the pretreatment, a measurement of non-cellulose glucose is possible and cellulose can then be calculated by difference from a sample in which the pretreatment has been included. About $14 \%$ of the glucose was recovered without the $\mathrm{H}_{2} \mathrm{SO}_{4}$ pretreatment. However, Cowie \& Hedges (1984b) found a $4 \%$ conversion of commercially prepared cellulose to glucose without the $\mathrm{H}_{2} \mathrm{SO}_{4}$ pretreatment. Therefore we estimate that non-cellulose glucose accounts for ca $10 \%$ of the total glucose pool in senescent $H$. wrightii and cellulose comprises the remaining $90 \%$. Notably, $82 \%$ of the total mannose pool also required pretreatment for recovery. Therefore, mannose, which is a $\mathrm{C}_{2}$ epimer of glucose, may be formed primarily as a hydrolysis product from the relatively large amount of glucose present in the hydrolysate mixtures.

\section{Soluble phenolic acids}

Three soluble phenolic acids were detected in low concentrations in the methanol extract of senescent tissue (Table 2). Vanillic acid was more abundant $\left[0.18 \mathrm{mg}\left(10 \mathrm{~g} \mathrm{AFDW}^{-1}\right]\right.$ than $p$-coumaric $[0.09 \mathrm{mg}$ $\left.(10 \mathrm{~g} \mathrm{AFDW})^{-1}\right]$ and ferulic acid $[0.13 \mathrm{mg}(10 \mathrm{~g}$ AFDW $\left.)^{-1}\right]$. These soluble phenolic acids made up ca $4 \%$ of the total phenol yield (Table 2) from CuO oxidation of senescent Halodule wrightii. Soluble phenolic acids were virtually absent from all litter bag samples (with the exception of low levels of ferulic acid after 24 d) which indicates that these compounds are rapidly leached from $H$. wrightii detritus.

In contrast to these relatively low concentrations of specific phenolic acids, Buchsbaum et al. (1991) report that fresh blades from the seagrass Zostera marina were comprised of ca $10 \%$ total soluble phenolics as measured using the Folin-Denis procedure after 
Table 2. Halodule wrightii. Phenol yields [mg phenol $\left.(10 \mathrm{~g} \text { AFDW })^{-1}\right]$ for green, senescent, decomposing and photobleached seagrass blades. Deviation: average percent mean deviation for decomposing samples (lignin-derived phenols only). VAL: vanillin; VON: acetovanillone; VAD: vanillic acid; SAL: syringaldehyde; SON: acetosyringone; SAD: syringic acid;

CAD: $p$-coumaric acid; FA.D: ferulic acid; $\Sigma 8$ : sum of all 8 phenols

\begin{tabular}{|c|c|c|c|c|c|c|c|c|c|}
\hline Sample & VAL & VON & VAD & $\mathrm{SAL}$ & SON & SAD & $C A D$ & FAD & $\sum 8$ \\
\hline \multicolumn{10}{|c|}{ Soluble phenols } \\
\hline Green & 0.00 & 0.00 & 0.15 & 0.00 & 0.00 & 0.00 & 0.13 & 0.13 & 0.41 \\
\hline Senescent & 0.00 & 0.00 & 0.18 & 0.00 & 0.00 & 0.00 & 0.09 & 0.13 & 0.40 \\
\hline \multicolumn{10}{|l|}{ Decomposing (d) } \\
\hline 24 & 0.00 & 0.00 & 0.00 & 0.00 & 0.00 & 0.00 & 0.00 & 0.10 & 0.10 \\
\hline 49 & 0.00 & 0.00 & 0.00 & 0.00 & 0.00 & 0.00 & 0.00 & 0.00 & 0.00 \\
\hline 136 & 0.00 & 0.00 & 0.00 & 0.00 & 0.00 & 0.00 & 0.00 & 0.00 & 0.00 \\
\hline 305 & 0.00 & 0.00 & 0.00 & 0.00 & 0.00 & 0.00 & 0.00 & 0.00 & 0.00 \\
\hline 367 & 0.00 & 0.00 & 0.00 & 0.00 & 0.00 & 0.00 & 0.00 & 0.00 & 0.00 \\
\hline 419 & 0.00 & 0.00 & 0.00 & 0.00 & 0.00 & 0.00 & 0.00 & 0.00 & 0.00 \\
\hline \multicolumn{10}{|c|}{ Ester-bound phenols } \\
\hline Green & 0.00 & 0.00 & 2.38 & 0.00 & 0.00 & 0.07 & 1.16 & 0.44 & 4.05 \\
\hline Senescent & 0.00 & 0.00 & 2.55 & 0.00 & 0.00 & 0.06 & 1.10 & 0.32 & 4.04 \\
\hline \multicolumn{10}{|l|}{ Decomposing (d) } \\
\hline 24 & 0.00 & 0.00 & 0.47 & 0.00 & 0.00 & 0.00 & 0.41 & 0.10 & 0.97 \\
\hline 49 & 0.00 & 0.00 & 0.05 & 0.00 & 0.00 & 0.00 & 0.20 & 0.15 & 0.40 \\
\hline 136 & 0.00 & 0.00 & 0.00 & 0.00 & 0.00 & 0.00 & 0.16 & 0.00 & 0.16 \\
\hline 305 & 0.00 & 0.00 & 0.00 & 0.00 & 0.00 & 0.00 & 0.00 & 0.00 & 0.00 \\
\hline 367 & 0.00 & 0.00 & 0.00 & 0.00 & 0.00 & 0.00 & 0.00 & 0.00 & 0.00 \\
\hline 419 & 0.00 & 0.00 & 0.00 & 0.00 & 0.00 & 0.00 & 0.00 & 0.00 & 0.00 \\
\hline \multicolumn{10}{|c|}{ Lignin-derived phenols ${ }^{a}$} \\
\hline Green & 1.47 & 0.54 & 4.31 & 1.54 & 0.60 & 0.77 & 1.21 & 0.65 & 7.63 \\
\hline Senescent & 1.56 & 0.33 & 0.97 & 1.01 & 0.54 & 0.50 & 0.09 & 0.56 & 6.00 \\
\hline \multicolumn{10}{|l|}{ Decomposing (d) } \\
\hline 24 & 1.60 & 0.28 & 0.25 & 0.79 & 0.46 & 0.49 & 0.29 & 0.47 & 4.89 \\
\hline 49 & 1.41 & 0.24 & 0.31 & 0.64 & 0.37 & 0.51 & 0.32 & 0.31 & 4.76 \\
\hline 136 & 1.50 & 0.34 & 0.59 & 1.17 & 0.55 & 0.41 & 0.22 & 0.50 & 5.50 \\
\hline 166 & 1.40 & 0.26 & 0.58 & 0.91 & 0.47 & 0.38 & 0.43 & 0.39 & 4.81 \\
\hline 195 & 1.73 & 0.67 & 0.66 & 1.18 & 0.80 & 0.68 & 0.56 & 0.58 & 6.84 \\
\hline 227 & 1.44 & 0.50 & 0.52 & 0.82 & 0.52 & 0.45 & 0.50 & 0.43 & 5.18 \\
\hline 269 & 1.72 & 0.40 & 0.49 & 1.16 & 0.87 & 0.50 & 0.40 & 0.48 & 6.03 \\
\hline 305 & 1.45 & 0.45 & 0.58 & 0.98 & 0.45 & 0.44 & 0.44 & 0.53 & 5.34 \\
\hline 339 & 2.25 & 0.54 & 0.65 & 1.82 & 1.29 & 0.66 & 0.23 & 0.58 & 8.02 \\
\hline 367 & 1.77 & 0.44 & 0.54 & 1.03 & 0.49 & 0.45 & 0.22 & 0.40 & 5.33 \\
\hline 395 & 2.61 & 0.36 & 0.71 & 0.83 & 0.38 & 0.27 & 0.42 & 0.43 & 6.01 \\
\hline \multirow[b]{2}{*}{ Deviation: } & 2.04 & 0.43 & 0.82 & 1.03 & 0.31 & 0.82 & 0.36 & 0.44 & 6.25 \\
\hline & $(11 \%)$ & $(20 \%)$ & $(10 \%)$ & $(15 \%)$ & $(14 \%)$ & $(15 \%)$ & $(12 \%)$ & $(13 \%)$ & \\
\hline Photobleached & 0.00 & 0.00 & 0.00 & 0.00 & 0.00 & 0.00 & 0.00 & 0.70 & 0.70 \\
\hline
\end{tabular}

extraction in $80 \%$ methanol. This colorimetric determination of the total soluble phenolic pool includes measurement of a heterogeneous mixture of monomeric and polymeric phenolic compounds. If these 2 different species of seagrass are similar in their total phenolic composition, then the phenolic acids that we identified comprise only a small fraction of the total phenols in the methanol soluble extract.

\section{Ester-bound phenols}

Four phenols, vanillic, syringic, $p$-coumaric and ferulic acid, were identified in the base hydrolysates (Table 2). Ester-bound vanillic, p-coumaric and ferulic acid accounted for 93,92 and $71 \%$ respectively of their totals (soluble + ester-bound phenols) released from senescent tissue upon hydrolysis in base indicating 
that these ester-bound phenols are approximately an order of magnitude more abundant than soluble phenolic acids in Halodule wrightii. These phenolic acids were the dominant components of the total soluble and ester-bound phenols in H. wrightii. Vanillin, acetovanillone, syringaldehyde, and acetosyringone were undetectable in the basic hydrolysate (Table 2), although vanillin has been reported in base extracts of soils and plant roots (Whitehead et al. 1981). However, their inherently low concentrations in seagrass tissues make detection and quantification difficult and trace amounts of some of these compounds may in fact be released during mild base hydrolysis.

Over $75 \%$ of the ester-bound phenols were lost from litter bags after only $24 \mathrm{~d}$ in the field (Table 2), indicating that ester-bound phenols are labile relative to bulk tissue and susceptible to leaching, microbial decomposition, or both. Between 24 and $136 \mathrm{~d}$, the percentage of initial ester-bound phenol remaining had decreased to $<5 \%$ and was comprised solely of $p$ coumaric acid. As seen from the decomposition series, the large pool of relatively labile soluble and esterbound phenols, initially present in these tissues, was lost during the first few months of decomposition.

\section{Lignin-derived phenols}

Lignin is a heteropolymer of phenylpropane subunits bound by ether and carbon-carbon linkages and is unique to vascular plants (Sarkanen \& Ludwig 1971). Rigorous conditions, such as alkaline CuO oxidation, are required for cleavage of the carbon-carbon and ether bonds in lignin. The $\mathrm{CuO}$ oxidation of lignin produces 11 predominant phenolic monomers, and these are separated into 4 families: the p-hydroxy, vanillyl, syringyl and cinnamyl phenols ( $\mathrm{P}, \mathrm{V}, \mathrm{S}, \mathrm{C}$ respectively). The $p$-hydroxy, vanillyl and syringyl families each have 3 members, an acid, aldehyde and ketone, and the 2 cinnamyl phenols ( $p$-coumaric and ferulic acid) are both acids, $p$-Hydroxybenzaldehyde and $p$ hydroxybenzoic acid may have both lignin (Sarkanen \& Ludwig 1971) and non-lignin sources (Hedges \& Parker 1976), therefore, $p$-hydroxy phenols are not treated further in this manuscript

Many of the individual phenols produced from lignin during $\mathrm{CuO}$ oxidation are also present in soluble form or may be ester-bound to cell wall constituents (this study, Table 2; Higuchi et al. 1967, Hartley 1973). As demonstrated above, monomeric soluble and esterbound phenols are readily extracted in mild base, whereas lignin-derived phenols are not. In this study, we have taken a new approach to more accurately quantify the $\mathrm{CuO}$ oxidation products of lignin by separating the total phenol yields produced upon
CuO oxidation into 3 categories: soluble, ester-bound and lignin-derived phenols. We have defined ligninderived phenols as those phenols produced from the CuO oxidation of whole tissue minus phenols released after mild base hydrolysis. Using this definition, we are now able to exclude soluble and ester-bound phenols from those which are derived exclusively from lignin.

Other studies have questioned whether or not lignin is present in seagrasses (see Buchsbaum et al. 1991 and references therein). Part of this discrepancy lies in the methodologies used to measure lignin. Acid detergent or Klason lignin (Klumpp \& van der Valk 1984, Buchsbaum et al. 1991), acetyl bromide digestion (Wilson et al. 1986) and conjugated and non-conjugated phenols (Baydoun \& Brett 1985) have all been used to measure lignin in seagrasses. These methods rely on gravimetric or colorimetric measurements for final determination of lignin and are subject to contamination by non-lignin compounds, such as tannins and cutin (Benner et al. 1990b). Alternatively, molecular-level analyses of $\mathrm{CuO}$ oxidation products (Hedges \& Mann 1979, this study) or pyrolysis mass spectrometry (Boon \& Haverkamp 1982) provide positive identification of lignin through recognition of characteristic compounds or mass fragments.

As seen in Table 2, all 8 characteristic lignin-derived phenols were present in all litter-bag samples. Based on the presence of lignin-derived $\mathrm{CuO}$ oxidation products (which were verified by GC/MS), we provide unambiguous evidence for the presence of lignin in Halodule wrightii. For comparison, Haddad \& Martens (1987) also detected vanillyl, syringyl and cinnamyl phenols in the seagrasses $H$. wrightii and Ruppia sp. These authors also analyzed Zostera marina, another species of seagrass, and found vanillyl but no syringyl phenols. Likewise, Wilson et al. (1985) also analyzed Z. marina and found vanillyl but no syringyl phenols, while Hedges \& Mann (1979) did not find any vanillyl or syringyl phenols in $Z$. marina. Based on these studies, the lignin content of $Z$. marina is questionable because it lacks the characteristic syringyl phenols. Furthermore, Boon \& Haverkamp (1982) analyzed Z. marina using pyrolysis mass spectrometry and reported that peak intensities for the lignin-derived pyrolysis products were 'rather unusual'. A more comprehensive survey of other seagrass species, which includes quantification of soluble and ester-bound phenols, is needed to determine whether other species of seagrass contain lignin.

Green and senescent tissue had higher yields of lignin-derived phenols ( $\Sigma 8$; Table 2 ) than $24 \mathrm{~d}$ tissue indicating losses of lignin during the leaching stage of decomposition. Between 24 and 419 d, $\sum 8$ was variable and did not change significantly during decomposition $(p>0.05)$. Vanillin and syringaldehyde were the pre- 
dominant components produced from Halodule wrightii lignin throughout the study. Vanillyl yields were slightly higher than syringyl which in turn were slightly higher than cinnamyl phenol yields, and this pattern varied little during decomposition. Total yields for green and senescent material were 3 to 8 times lower than most other herbaceous angiosperm tissues (Hedges \& Mann 1979) due to a much lower lignin content in seagrasses.

Particulate material which had been hydrolyzed in $1 \mathrm{~N} \mathrm{NaOH}$ was subjected to $\mathrm{CuO}$ oxidation and produced consistently lower individual phenol yields (data not shown) and a substantially lower total phenol content for green, senescent and $24 \mathrm{~d}$ detritus $[2.49,3.21$ and $3.08 \mathrm{mg}(10 \mathrm{~g}$ AFDW $)^{-1}$ respectivelyl when compared to lignin-derived phenols [7.63, 6.00 and $4.89 \mathrm{mg}$ (10 g AFDW) ${ }^{-1}$; Table 2] from untreated starting material. This indicates that mild base hydrolysis removes some polymeric lignin in addition to soluble and esterbound phenols. These results agree with those from Benner et al. (1984). Using a variety of estuarine macrophytes, these authors found that less than $30 \%$ of base soluble lignin was determined to be ether soluble (and potentially identifiable as phenolic acids), leaving the majority of this base-soluble lignin uncharacterized at the molecular level. Mild base hydrolysis can be used to measure the soluble and ester-bound phenol content, which, when subtracted from total phenols produced upon $\mathrm{CuO}$ oxidation of whole tissue, will provide a measure of lignin-derived phenols. However, due to the substantial quantities of base-soluble lignin lost from the particulate material upon hydrolysis, sequential treatment of the same sample of dried plant material to measure both basesoluble phenols and lignin-derived phenols is not possible unless the additional base-soluble lignin is accounted for.

\section{Cutin-derived fatty acids}

$\mathrm{C}_{16}$ and $\mathrm{C}_{18}$ hydroxylated fatty acids are the 2 major families of cutin acids produced upon $\mathrm{CuO}$ oxidation of cutin polymer (Goni \& Hedges 1990a). The complete absence of any cutin-derived $C_{18}$ fatty acids from Halodule wrightii tissue suggests that this angiosperm species may no longer utilize the biochemical pathways for synthesis of the $\mathrm{C}_{18}$ cutin acids (Kolattukudy \& Espelie 1985). Four members of the $C_{16}$ family [16hydroxyhexadecanoic acid $\left(\omega-C_{16}\right)$; hexadecane-1,16-
Table 3. Halodule wrightii. Cutin acid yields ( $\mathrm{mg} \mathrm{g}^{-1}$ AFDW) for green, enescent, decomposing and photobleached seagrass blades. Deviation: verage percent mean deviation for decomposing samples. $\omega-C_{16}: 16-$ droxyhexadecanoic acid; $C_{16} D A$ : hexadecane-1,16-dioic acid; $x, \omega-C_{16}$ : 9 or 10).16-dihydroxyhexadecanoic acid; $x-C_{16}$ DA: (7 or 8)-hydroxyhexadecane-1,16-dioic acid; $\Sigma \mathrm{CA}$ : sum of cutin-derived acids

\begin{tabular}{|c|c|c|c|c|c|}
\hline Sample & $\omega-C_{16}$ & $C_{i 0} D A$ & $x, \omega-C_{10}$ & $\mathrm{X}-\mathrm{C}_{16} \mathrm{DA}$ & $\sum \mathrm{CA}$ \\
\hline Green & 0.09 & 0.05 & 0.58 & 1.23 & 1.95 \\
\hline Senescent & 0.09 & 0.03 & 0.56 & 1.03 & 1.71 \\
\hline \multicolumn{6}{|l|}{ Decomposing (d) } \\
\hline 24 & 0.13 & 0.04 & 0.73 & 1.17 & 2.07 \\
\hline 49 & 0.09 & 0.04 & 0.68 & 1.12 & 1.93 \\
\hline 136 & 0.12 & 0.04 & 0.89 & 1.44 & 2.48 \\
\hline 166 & 0.11 & 0.04 & 0.76 & 1.21 & 2.11 \\
\hline 195 & 0.11 & 0.04 & 0.91 & 1.35 & 2.41 \\
\hline 227 & 0.12 & 0.04 & 1.01 & 1.49 & 2.66 \\
\hline 269 & 0.11 & 0.05 & 1.15 & 1.85 & 3.15 \\
\hline 305 & 0.07 & 0.04 & 0.94 & 1.39 & 2.44 \\
\hline 339 & 0.09 & 0.03 & 0.88 & 1.13 & 2.12 \\
\hline 367 & 0.08 & 0.03 & 0.82 & 0.61 & 1.54 \\
\hline 395 & 0.05 & 0.08 & 0.60 & 0.91 & 1.64 \\
\hline 419 & 0.03 & 0.14 & 0.39 & 0.84 & 1.40 \\
\hline Deviation: & $(16 \%)$ & $(10 \%)$ & $(12 \%)$ & $(12 \%)$ & \\
\hline Photobleached & 0.03 & 0.04 & 0.33 & 1.28 & 1.68 \\
\hline
\end{tabular}

dioic acid $\left(\mathrm{C}_{16} \mathrm{DA}\right) ;(8,9$ or 10$), 16$-dihydroxyhexadecanoic acid $\left(\mathrm{x}, \omega-\mathrm{C}_{16}\right)$; and $(7$ or 8$)$-hydroxyhexadecane-1,16-dioic acid ( $\left.x-C_{16} D A\right)$ ) were obtained from senescent tissues in yields of $0.09,0.03,0.56$ and $1.03 \mathrm{mg} \mathrm{g}^{-1}$ AFDW, respectively (Table 3 ). The lack of $\mathrm{C}_{18}$ acids and predominant $\mathrm{x}, \omega-\mathrm{C}_{16}$ and $\mathrm{x}-\mathrm{C}_{16} \mathrm{DA}$ acids make $H$. wrightii cutin rather unusual with respect to other monocotyledons included in a survey of 67 plant species subjected to $\mathrm{CuO}$ oxidation (Goni \& Hedges 1990b). H. wrightii also differs from the seagrass Zostera marina which produced only trace amounts of $\mathrm{C}_{16} \mathrm{DA}$ (Goni \& Hedges 1990b).

Both the $\mathrm{C}_{15} \mathrm{DA}$ and $\omega-\mathrm{C}_{16}$ acids occur near the detection limit, making trends in abundance difficult to detect. Yields of the more abundant $x, \omega-C_{16}$ and $x-C_{16} D A$ acids (Table 3 ) exhibited 2 apparent trends. During the first $269 \mathrm{~d}$ of the study, which corresponds to ca $72 \%$ organic mass loss, yields of both of these hydroxy-acids increased to an even greater extent than did lignin. Beyond 269 d, these yields declined to a point in which the highly degraded detritus was slightly depleted in these compounds relative to the starting material. These 2 phases which characterize the decomposition of cutin appear to be unique among measured classes of major biochemical constituents in this as well as other studies. It appears that the physical integrity of the cuticle remains at least partially intact during leaching and the earlier stages of decomposition, but eventually breaks down at which time the component hydroxy fatty acids degrade more rapidly. 


\section{Relative stabilities}

In order to compare the short- and longterm relative stabilities of individual constituents, early losses which result from leaching must first be considered. Whereas the largest loss of total organic mass occurred during the first $24 \mathrm{~d}$ of decomposition, many of the specific compounds measured did not show this pattern. For example, vanillin yields changed little during the first $24 \mathrm{~d}$ of decomposition. This apparent stability was also evidenced by the fact that vanillin did not appear to be released in ester or soluble form after treatment with $1 \mathrm{~N} \mathrm{NaOH}$. Therefore, early losses due to leaching are not an important factor in determining the decomposition dynamics of the phenolic precursors of vanillin. Alternatively, galactose yields were considerably reduced during the first $49 \mathrm{~d}$ of decomposition, but beyond Day 49 , yields progressively increased through the duration of the study. In this instance, it is likely that there are 2 distinct sources within Halodule wrightii tissue which yield galactose upon hydrolysis: one which is relatively labile and contributes to the observed early losses and a second which is stable relative to bulk tissue and is selectively preserved throughout decomposition. These variations in the decomposition kinetics of individual compounds may be important depending on which phase of decomposition is being studied. Large early losses due to leaching processes are important in terms of vascular plants as sources of dissolved organic matter and also for potential changes which may influence biomarker applications. Such losses, however, are not necessarily representative of the latter stages of decomposition.

In order to properly evaluate the temporal behavior of the various constituents, the percentages of initial mass remaining are calculated as:

$$
\begin{aligned}
\% \text { remaining } & =(\text { yield } / \text { initial yield }) \\
& \times[1-(\% \text { AFDW loss } / 100)] \times 100 .
\end{aligned}
$$

Compounds which have a higher '\% remaining' than '\% AFDW remaining' have become enriched relative to initial organic mass while those with a lower $\%$ remaining' are relatively depleted.

Neutral sugars comprise the largest measured pool of organic matter lost during leaching (Table 1), and the percent initial yields of individual neutral sugars from decomposing Halodule wrightii blades are depicted in Fig. 2. Changes during the first $24 \mathrm{~d}$ of decomposition provide an indication as to which constituents are most susceptible to leaching, however, total neutral sugar yields as well as initial yields of each component must also be considered in order to estimate relative inputs of individual sugars to the dissolved pool. Senescent $H$. wrightii lost $35.5 \%$ (i.e. $355 \mathrm{mg} \mathrm{g}^{-1}$ AFDW) of its total organic mass after $24 \mathrm{~d}$ in the field (Fig. 1). Of this, $63.1 \mathrm{mg} \mathrm{g}^{-1}$, or $18 \%$ of the total organic mass was accounted for as neutral sugars, leaving $82 \%$ of the organic matter lost during leaching as yet chemically undefined. Glucose was the major sugar removed during leaching, accounting for $61 \%$ (38.6 $\mathrm{mg} \mathrm{g}^{-1}$ AFDW) of the total neutral sugar fraction lost. Losses for other sugars range from $1.2 \mathrm{mg} \mathrm{g}^{-1}$ AFDW for fucose to $6.4 \mathrm{mg} \mathrm{g}^{-1}$ AFDW for galactose after the first $24 \mathrm{~d}$ of decomposition. It is interesting to note that glucose, which is least susceptible to leaching, still accounts for the majority of the neutral sugar lost during the first $24 \mathrm{~d}$ of decomposition. Sources in addition to structural polymers, such as sucrose, are present in relatively fresh seagrass detritus and may account for some of the early rapid neutral sugar losses.

A considerably different pattern of distribution of individual sugars becomes evident when highly degraded samples are compared to the initial senescent material. Using the Day 419 data from Fig. 2, a longterm stability series for the individual sugars in highly degraded Halodule wrightii detritus from most to least stable is: mannose $>$ fucose $>$ arabinose $\approx$ rhamnose $\approx$ AFDW $\approx$ galactose $=$ xylose $>$ glucose $\gg$ myoinositol. Clearly, patterns of loss for individual neutral sugars during the early stage of decomposition 10 to $24 \mathrm{~d})$ did not reflect these overall trends, indicating a shift in the neutral sugar content of detritus between the early and latter (post-leaching) stages of decomposition. This most likely reflects different processes (solubilization versus microbial decomposition) that are selective for certain forms of individual sugar sources. 


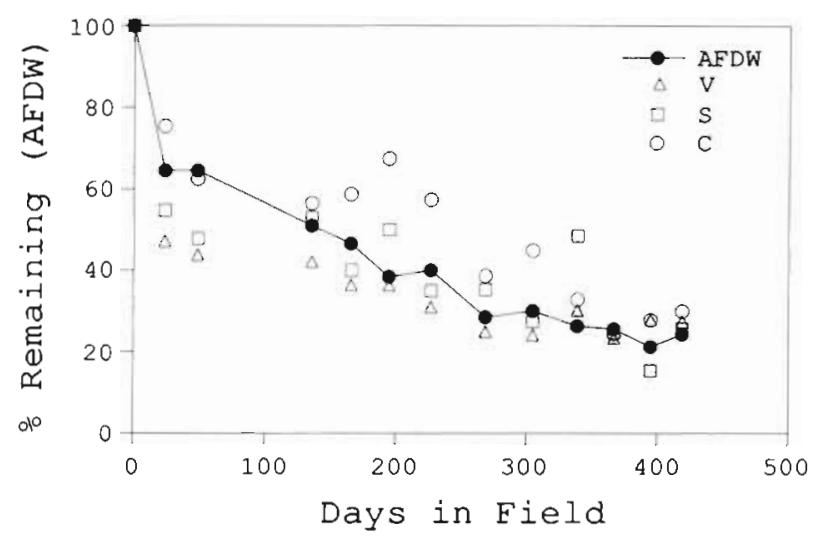

Fig. 3. Halodule wrightii. Percent remaining of individual lignin-derived phenol families from decomposing seagrass blades. Each symbol represents average values for replicate litter bags. $V$ : total yield of vanillyl phenols; $S$ : total yield of syringyl phenols; $C$ : total yield of cinnamyl phenols

Likewise, the \% remaining has been calculated for lignin-derived phenol families and plotted over the time series (Fig. 3). While considerable variation in $\%$ remaining for $\mathrm{V}, \mathrm{S}$ and $\mathrm{C}$ is evident throughout most of the study, the yields for the last several time points indicate that lignin phenols are present at near initial yields in highly degraded Halodule wrightii detritus resulting in a stability series: $C \approx S \approx V \approx A F D W$ for lignin-derived phenols. Unlike neutral sugars, distributional patterns of lignin-derived phenols in highly degraded detritus were similar to that of the initial senescent material.

Individual biochemical constituents may also be grouped in order to evaluate the long-term relative

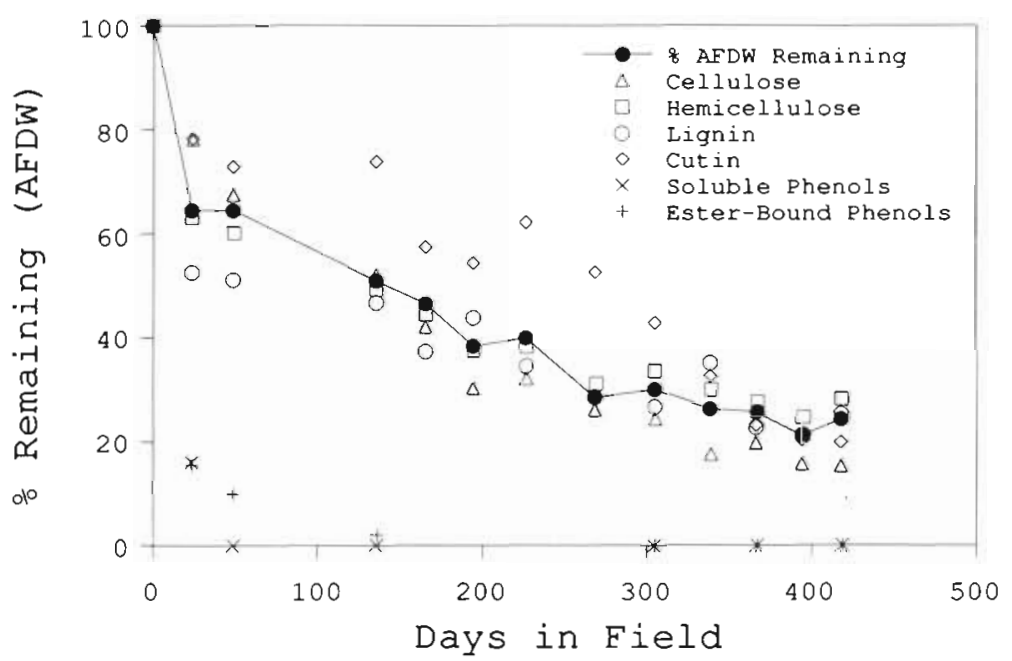

Fig. 4. Halodule wrightii. Percent remaining of major polymers and soluble and ester-bound phenols associated with decomposing seagrass blades. Each symbol represents average values for replicate litter bags stability of the major polymers from which they arise. In this study, the entire glucose pool is taken to represent cellulose (see above), all remaining neutral sugars except myo-inositol are grouped and designated as hemicellulose, lignin is represented by the sum of all lignin-derived $\mathrm{V}, \mathrm{S}$ and $\mathrm{C}$ phenols and cutin is taken as the sum of all 4 cutin-derived hydroxy acids. In a similar manner as above, the \% remaining have been calculated and plotted in order to provide the clearest representation of the long-term behavior of these major biochemical pools (Fig. 4). We have included soluble and ester-bound phenols for comparison to the other measured constituents. Note, however, that their relative stabilities are determined during the first 0 to $200 \mathrm{~d}$ of decomposition (Table 2). With the exception of cutin, the major biochemical constituents follow AFDW losses beyond about $100 \mathrm{~d}$ of decomposition. A stability series for these constituents, based on the most highly degraded samples, from most to least stable is: hemicellulose $\approx$ lignin $\approx$ AFDW $>$ cutin $>$ cellulose $\gg$ esterbound phenols $>$ soluble phenols. Overall, the relative abundance of the major polymers appears only slightly different in the most highly degraded detritus when compared to freshly senescent material

\section{Biomarker applications}

The abundance and composition of phenols derived from $\mathrm{CuO}$ oxidation are diagnostic of the presence and type of vascular plant tissues in environmental samples and have received considerable attention as biomarker compounds in marine environments (Hedges \& Mann 1979). Previous studies have used CuO oxidation data to determine vascular plant inputs to depositional environments (Gardner \& Menzel 1974, Hedges \& Parker 1976 , Hedges et al. 1984, Wilson et al. 1985 , Requejo et al. 1986, Haddad \& Martens 1987. Hamilton \& Hedges 1988) and to pools of dissolved organic carbon in both freshwater and marine environments (Ertel et al. 1984, Meyers-Schulte \& Hedges 1986, Moran \& Hodson 1990).

In addition to providing a biomarker which is unique to vascular plants, the CuO oxidation products of lignin contain more detailed information characteristic of the plant tissue source. Vanillyl phenols are predominant reaction products of woody and herbaceous tissue. Vanillyl phenols are characteristic of both gymnosperm and angiosperm $\mathrm{CuO}$ oxidation products, but syringyl phenols are virtually absent from gymnosperm tis- 
Table 4. Halodule wrightil. Lignin-derived parameters for green, senescent and decomposing seagrass blades. Green, senescent and 24 to $136 \mathrm{~d}$ tissue calculated using total phenols produced upon $\mathrm{CuO}$ oxidation minus soluble and ester-bound phenols. Beyond Day 136, whole material is used because soluble and ester-bound are virtually absent. $\mathrm{S} / \mathrm{V}$. weight ratio of syringyl phenols (SAL + SON + SAD) to vanillyl phenols (VAL + VON + VAD); CN: weight ratio of cinnamyl (CAD + FAD) phenols to vanillyl (VAL + VON + VAD) phenols; $(\mathrm{Ad} / \mathrm{Al})_{\text {w }}$. weight ratio of vanillic acid to vanillin; $(\mathrm{Ad} / \mathrm{Al})_{s}$ : weight ratio of syringic acid to syringaldehyde. Other abbreviations as in Table 2

\begin{tabular}{|lcccc|}
\hline Sample & $\mathrm{S} / \mathrm{V}$ & $\mathrm{C} / \mathrm{V}$ & $(\mathrm{Ad} / \mathrm{Al})_{\mathrm{V}}$ & $(\mathrm{Ad} / \mathrm{Al})_{\mathrm{S}}$ \\
\hline Green & 0.46 & 0.29 & 2.93 & 0.50 \\
Senescent & 0.71 & 0.23 & 0.62 & 0.49 \\
Decomposing $(\mathrm{d})$ & & & & \\
24 & 0.82 & 0.35 & 0.16 & 0.62 \\
49 & 0.78 & 0.32 & 0.22 & 0.80 \\
136 & 0.88 & 0.30 & 0.39 & 0.35 \\
166 & 0.79 & 0.37 & 0.41 & 0.41 \\
195 & 0.87 & 0.37 & 0.38 & 0.57 \\
227 & 0.72 & 0.37 & 0.36 & 0.55 \\
269 & 0.97 & 0.34 & 0.29 & 0.43 \\
305 & 0.76 & 0.39 & 0.40 & 0.45 \\
339 & 1.10 & 0.24 & 0.29 & 0.36 \\
367 & 0.72 & 0.22 & 0.31 & 0.43 \\
395 & 0.40 & 0.23 & 0.27 & 0.32 \\
419 & 0.66 & 0.24 & 0.40 & 0.79 \\
\hline
\end{tabular}

sues (Hedges \& Mann 1979). Lignin-derived cinnamyl phenols are produced almost exclusively from the oxidation of herbaceous tissues and therefore the presence of cinnamyl phenols indicates the presence of vascular plant herbaceous tissue (Hedges \& Mann 1979).

Ratios of syringyl to vanillyl ( $\mathrm{S} / \mathrm{V}=$ sum of syringyl phenols divided by sum of vanillyl phenols) and cinnamyl to vanillyl $(\mathrm{C} / \mathrm{V}=$ sum of cinnamyl phenols divided by sum of vanillyl phenols) indicate plant type (angiosperm or gymnosperm) and tissue type (herbaceous or woody), and are key parameters which can help to decipher source inputs to heterogeneous mixtures (Hedges \& Mann 1979). Previous investigations using a variety of plants have shown that associated lignin parameters are subject to selective decomposition processes (Hedges \& Weliky 1989, Benner et al. 1990a, 1991). For example, $\mathrm{C} / \mathrm{V}$ in particular has been shown to decrease with increasing decomposition owing to the preferential loss of C phenols (Hedges \& Weliky 1989, Benner et al. 1991. Haddad et al. 1992). In this study, no significant linear trends $(p>0.05)$ were evident in either the S/V or C/V ratios (Table 4 ; green tissue is excluded from the decomposition series). Although variable, when these parameters are calculated exclusively from lignin-derived phenols, S/V and $C / V$ ratios are similar in senescent and highly degraded tissue.
Other lignin parameters can be used as indicators of the diagenetic state of vascular plant organic matter. For example, Hedges et al. (1988) demonstrated elevated vanillic acid to vanillin ratios, $(\mathrm{Ad} / \mathrm{Al})_{\mathrm{v}}$ in woods which had been degraded by terrestrial white-rot fungi. In the case of Halodule wrightii, a non-woody tissue which had been decomposed in the water column, no significant trend $(p>0.05)$ was apparent in $(\mathrm{Ad} / \mathrm{Al})_{\mathrm{v}}$ or $(\mathrm{Ad} / \mathrm{Al})_{\mathrm{s}}$, syringic acid to syringaldehyde ratio, throughout the duration of the study (Table 4). Results from the decomposition of other non-woody plant tissues including conifer needles (Hedges \& Weliky 1989), mangrove leaves (Benner et al. 1990a) and cordgrass (Benner et al. 1991), have indicated nonselective degradation of the lignin subunits which produce these acids and aldehydes upon CuO oxidation. Bacteria are the primary organisms responsible for the degradation of lignin in marine environments (Benner et al. 1986a), and the associated mechanisms appear to be nonselective for the macromolecular precursors which yield vanillyl and syringyl phenols upon $\mathrm{CuO}$ oxidation.

Earlier studies which have investigated the molecular-level composition of lignin using $\mathrm{CuO}$ oxidation have not distinguished soluble and ester-bound phenols from the corresponding total individual phenol yields. We found soluble and ester-bound phenols to be quantitatively important in fresh and relatively recent Halodule wrightii detritus. Total lignin-derived phenols $\left(\sum 8\right), \mathrm{C} / \mathrm{V}$ and $(\mathrm{Ad} / \mathrm{Al})$, ratios would be elevated and the $\mathrm{S} / \mathrm{V}$ ratio reduced relative to the reported values if these corrections had not been made. Therefore, measurement of soluble and esterbound phenols was necessary to accurately calculate total lignin-derived phenols and associated ligninderived parameters. If a similar trend of elevated phenolic acids holds for other plant species, then it may be necessary to reevaluate the phenol content of fresh tissue endmembers in order to explain rapid early changes in the total phenol content. Using this new approach to characterize individual pools of phenols, we are now able to distinguish between changes primarily due to solubilization versus those related to the biodegradation of specific lignin subunits.

\section{Photobleached detritus}

Although the absolute age of the photobleached detritus is not known, Newell et al. (1986) point out that photobleached detritus at the supratidal level of the shoreline may degrade more slowly than that found at mid-tidal level. In the Laguna Madre, this material is abundant and represents detritus which has 
been subjected to periodic submergence, desiccation and exposure to direct sunlight. Lignin phenol yields from photobleached Halodule wrightii blades were dramatically different than those from the litter bag samples and unlike any reported for other vascular plant tissues since only ferulic acid was detected in the photobleached detritus (Table 2). This virtual lack of lignin phenols may be attributed to photodegradation of aromatic structures in the seagrass blades because phenolic constituents are susceptible to photooxidation (Sarkanen \& Ludwig 1971). This is further supported by the fact that seagrass blades lying directly below the photobleached layer contained lignin-derived phenol yields comparable in magnitude to litter bag samples (data not shown). Soluble and ester-bound phenolic acids released from detritus during leaching are also likely to be susceptible to photooxidation and photobleaching may facilitate solution of partially degraded phenols. Photooxidation may represent a major mechanism for degradation of phenolic compounds in the dissolved phase.

In contrast to the absence of phenols, increased neutral sugar yields, due primarily to elevated glucose and xylose yields, indicate that neutral sugars are not susceptible to photooxidation. The higher yields for this class of compounds are well within the range expected for passive concentration and thus likely result from selective loss of other biochemical constituents within the detritus. The higher concentration of neutral sugars may also be an indication that little microbial degradation is taking place under the extremely dry and high ultraviolet light conditions. Cutin acid yields in photobleached detritus were similar to those of partially degraded litter-bag samples and, like neutral sugars, do not have the same susceptibility to photodegradation as the lignin component. Therefore, pathways of decomposition which alter the chemical composition of photobleached detritus have a different net result than those acting on completely submerged material demonstrating that photodegradation is an environmentally important degradative mechanism which may considerably alter the chemical composition of plant detritus.

\section{Ecological implications}

Estimations of decay rates from litter bag studies, while useful for making comparisons among plant species treated in a similar manner, are limited in their predictive capacity. Questions still remain regarding decay rates for highly degraded detritus and the types of models which are most representative of long-term decomposition (Moran et al. 1989). We omitted the first data point for modeling decay rates because of the exceptionally high weight loss due to leaching during the first $24 \mathrm{~d}$ of submergence. Exponential and linear decay models both yield a highly significant fit $(p<0.01)$ to the data set. The exponential decay model predicts that $5 \%$ of the original AFDW will remain after $930 \mathrm{~d}$ while the linear model predicts $5 \%$ of the original AFDW remaining after only $536 \mathrm{~d}$ in the field, a difference of about $400 \mathrm{~d}$ to account for $20 \%$ of the remaining detritus. This difference would be even greater if the calculation were taken to $1 \%$ of the initial starting material remaining. While this study is significant in that $76 \%$ of the decomposition has been documented, an important but as yet unpredictable phase of decomposition remains unstudied.

Processes which are involved in the decomposition of vascular plants, including leaching, fragmentation, photooxidation and biodegradation, all potentially result in selective decomposition thereby altering the ultrastructure of the residual particulate material. Interestingly, in the case of Halodule wrightii, the neutral sugar, lignin and cutin fractions were all found at similar levels in highly degraded tissue compared to freshly senescent material. At best, only minor trends for selective decomposition or enrichment were evident for any of these components, with the possible exception of cutin which may be predicted to selectively decompose beyond $419 \mathrm{~d}$. Apparently, with respect to these measured components, the ultrastructure of the highly degraded $H$. wrightii detritus does not reflect changes due to selective decomposition of these polymers.

Cellulose, hemicellulose and lignin typically account for $>75 \%$ of the biomass of woody plant tissues (Sjostrom 1981). In the case of Halodule wrightii, cellulose and hemicellulose together comprised ca $20 \%$ of the total organic mass and lignin and cutin collectively accounted for only a few percent. Similar concentrations of these biopolymers have been reported for other herbaceous plant tissues (Hedges \& Weliky 1989. Benner et al. 1990a). Given the biochemical complexity of herbaceous tissues and the lack of suitable molecular-level analyses for components such as tannins, it is unlikely that a comprehensive view of the chemical composition can be obtained using this approach. Solid-state ${ }^{13} \mathrm{C}$ nuclear magnetic resonance (NMR) has recently been used to provide a comprehensive view of the chemical constituents comprising leaf tissues (Hatcher 1987, Wilson et al. 1987, Benner et al. 1990b). These studies have revealed that aliphatic polymers, tannins and polysaccharides not accounted for by the neutral sugar analysis, such as the polyuronic acids of pectin and other polymers, can be major constituents of herbaceous plant tissues. This kind of approach is needed to gain a better understanding of the qualitative changes that take place during the 
decomposition of seagrasses and the influence of detritus quality on bioavailability and organic matter preservation.

Acknowledgements. The authors thank John Hedges and Miguel Goni for offering their expertise and advice and for use of their GC/MS facility at the University of Washington. We are especially grateful to John Hedges and 2 anonymous reviewers for thoughtful comments. We also appreciate helpful reviews from Miguel Goni, Dean Pakulski. Bopi Biddanda and Rainer Amon. We would also like to thank Brenda Hamman for the cellulose determinations. This research was supported by grant BSR 8910766 from the NSF, grant NA89AAD-SG139 from the NOAA Office of Sea Grant, and grants 4541 and 3658-264 from the Texas Higher Education Coordinating Board Advanced Technology Program. This is contribution number 871 from The University of Texas at Austin Marine Science Institute.

\section{LITERATURE CITED}

Baydoun, E. A., Brett, C. T (1985). Comparison of cell wall compositions of the rhizomes of three seagrasses. Aquat. Bot. 23: 191-196

Benner, R., Fogel, M. L., Sprague, E. K. (1991). Diagenesis of belowground biomass of Spartina alterniflora in salt marsh sediments. Limnol. Oceangr. 36: 1358-1374

Benner, R., Hatcher, P. G., Hedges, J. I. (1990b). Early diagenesis of mangrove leaves in a tropical estuary: bulk chemical characterization using solid-state ${ }^{13} \mathrm{C}$ NMR and elemental analysis. Geochim. Cosmochim. Acta 54 2003-2013

Benner, R., Hodson, R. E. (1985). Microbial degradation of the leachable and lignocellulosic components of leaves and wood from Rhizophora mangle in a tropical mangrove swamp. Mar. Ecol. Prog. Ser. 23: 221-230

Benner, R., K'nees, E., Hodson, R. E. (1988). Carbon conversion efficiency for bacterial growth on lignocellulose: implications for detritus-based food webs. Limnol. Oceanogr. 33: $1514-1526$

Benner, R., Maccubbin, A. E., Hodson, R. E. (1984). Preparation, characterization, and microbial degradation of specifically radiolabelled $\left[{ }^{14} \mathrm{C}\right]$ lignocelluloses from marine and freshwater macrophytes. Appl. environ. Microbiol. 47: 381-389

Benner, R., Moran, M. A., Hodson, R. E. (1986a). Biogeochemical cycling of lignocellulosic carbon in marine and freshwater ecosystems: relative contributions of procaryotes and eucaryotes. Limnol. Oceanogr. 31: 89-100

Benner, R., Peele, E. R., Hodson, R. E. (1986b). Microbial utilization of dissolved organic matter from leaves of the red mangrove, Rhizophora mangle, in the Fresh Creek Estuary, Bahamas. Estuar. coast. Shelf Sci. 23: 607-619

Benner, R., Weliky, K., Hedges, J. I. (1990a). Early diagenesis of mangrove leaves in a tropical estuary: molecular-level analyses of neutral sugars and lignin derived phenols. Geochim. Cosmochim. Acta 54: 1991-2001

Blum, L. K., Mills, A. L. (1991). Microbial growth and activity during the initial stages of seagrass decomposition. Mar. Ecol. Prog. Ser 70: 73-82

Boon, J. J., Haverkamp, J. (1982). Pyrolysis mass spectrometry of intact and decomposed leaves of Nuphar variegatum and Zostera marina, and some archeological eelgrass samples. Hydrobiol. Bull. 16: 71-82
Buchsbaum, R., Valiela, I., Swain, T., Dzierzeski, M., Allen, S. (1991). Available and refractory nitrogen in detritus of coastal vascular plants and macroalgae. Mar. Ecol. Prog. Ser. 72: 131-143

Chin-Leo, G., Benner, R. (1991). Dynamics of bacterioplankton abundance and production in seagrass communities of a hypersaline lagoon. Mar. Ecol. Prog. Ser. 73: 219-230

Cowie, G. L., Hedges, J. I. (1984a). Determination of neutral sugars in plankton, sediments, and wood by capillary gas chromatography of equilibrated isomeric mixtures. Anal. Chem. 56: 497-504

Cowie, G. L., Hedges, J. I. (1984b). Carbohydrate sources in a coastal marine environment. Limnol. Oceanogr. 48: 2075-2087

Drew, E. A. (1980). Soluble carbohydrate composition of seagrasses. In: Phillips, R. C., McRoy, C. P. (eds.) Handbook of seagrass biology. Garland STPM Press, New York, p. $247-260$

Eglington, G., Hunneman, D. H. (1968), Gas chromatographic-mass spectrometric studies of long-chain hydroxy acids-I. The constituent acids of apple cuticle. Phytochemistry 7: 313-322

Ertel, J. R., Hedges, J. I., Perdue, E. M. (1984). Lignin signature of aquatic humic substances. Science 223: $485-487$

Findlay, S., Carlough, L., Crocker, M. T., Gill, H. K., Meyer, J. L. Smith, P. J. (1986). Bacterial growth on macrophyte leachate and fate of bacterial production. Limnol. Oceanogr. 31 (6) 1335-1341

Fry, B., Parker, P. L. (1979). Animal diet in Texas seagrass meadows: ${ }^{13} \mathrm{C}$ evidence for the importance of benthic plants. Estuar. coast. mar. Sci. 8: 499-509

Gardner, W. S., Menzel, D. W. (1974). Phenolic aldehydes as indicators of terrestrially derived organic matter in the sea. Geochim. Cosmochim. Acta 38: 813-822

Godshalk, G. L., Wetzel, R. G. (1978). Decomposition of aquatic angiosperms. I. Dissolved components. Aquat. Bot. 5: $281-300$

Goni, M. A., Hedges, J. I. (1990a). Cutin derived CuO reaction products from purified cuticles and tree leaves. Geochim. Cosmochim. Acta 54: 3065-3072

Goni, M., Hedges, J. I. (1990b). Potential applications of cutinderived $\mathrm{CuO}$ reaction products for discriminating vascular plant sources in natural environments. Geochim. Cosmochim. Acta 54: 3073-3081

Goni, M., Hedges, J. I. (1990c). The diagenetic behavior of cutin acids in buried conifer needles and sediments from a coastal marine environment. Geochim. Cosmochim. Acta 54: 3083-3093

Goni, M. A., Hedges, J. I. (1992). Lignin dimers: structures, distribution and potential geochemical applications. Geochim. Cosmochim. Acta. 56: 4025-4043

Haddad, R. L., Martens, C. S. (1987). Biogeochemical cycling in an organic-rich coastal marine basin. 9. Sources and accumulation rates of vascular plant-derived organic material. Geochim. Cosmochim. Acta 51: 2991-3001

Haddad, R. I., Newell, S. Y., Martens, C. S., Fallon, R. D. (1992). Early diagenesis of lignin-associated phenolics in the salt marsh grass Spartina alterniflara. Geochim. Cosmochim. Acta 56: 3751-3764

Hamilton, S. E., Hedges, J. I. (1988). The comparative geochemistries of lignins and carbohydrates in an anoxic fjord. Geochim. Cosmochim. Acta 52: 129-142

Harrison, P. G. (1989). Detrital processing in seagrass systems: a review of factors affecting decay rates, remineralization and detritivory. Aquat. Bot. 23: 263-288

Harrison, P. G., Chan, A. T. (1980). Inhibition of the growth of micro-algae and bacteria by extracts of eelgrass (Zostera 
marina) leaves. Mar. Biol. 61: 21-26

Harrison, P. G., Mann, K. H. (1975). Detritus formation from eelgrass (Zostera marina L.): the relative effects of $\mathrm{frag}$ mentation, leaching, and decay. Limnol. Oceanogr.: 20(6) $924-934$

Hartley, R. D. (1973). Carbohydrate esters of ferulic acid as components of cell-walls of Lolium Multiflorum. Phytochemistry 12:661-665

Hatcher, P. G., (1987). Chemical structural studies of natural lignin by dipolar dephasing solid-state ${ }^{13} \mathrm{C}$ nuclear magnetic resonance. Org. Geochem. 11:31-39

Hedges, J. I., Blanchette, R. A., Weliky, K., Devol, A. H. (1988). Effects of fungal degradation on the CuO oxidation products of lignin: A controlled laboratory study. Geochim. Cosmochim. Acta 52: 2717-2726

Hedges, J. I., Clark, W. A., Cowie, G. L. (1988). Organic matter sources to the water column and surficial sediments of a marine bay. Limnol. Oceanogr. 33: 1116-1136

Hedges, J. I., Ertel, J. R. (1982). Characterization of lignin by gas chromatography of cupric oxide oxidation products Anal. Chem. 54: 174-178

Hedges, J. I., Mann, D. C. (1979). The characterization of plant tissues by their lignin oxidation products. Geochim. Cosmochim. Acta 43: 1803-1807

Hedges, J. I., Parker, P. L. (1976). Land derived organic matter in surface sediments from the Gulf of Mexico. Geochim. Cosmochim. Acta 40: 1019-1029

Hedges, J. I., Turin, H. J., Ertel, J. R. (1984). Sources and distribution of sedimentary organic matter in the Columbia River drainage basin, Washington and Oregon. Limnol. Oceanogr. 29: 35-36

Hedges, J. I., Weliky, K. (1989). Diagenesis of conifer needles in a coastal marine environment. Geochim. Cosmochim. Acta 53: 2659-2673

Higuchi, T., Ito, Y., Shimada, M., Kawamura, I. (1967). Chemical properties of milled wood lignin of grasses. Phytochemistry 6:1551-1556

Holloway, P. J. (1973). Cutins of Malus pumila fruits and leaves. Phytochemistry 12: 2913-2920

Holloway, P. J. (1982). The chemical constitution of plant cutins. In: Cutler, D. F., Alvin, K. L., Price, C. E. (eds.) The plant cuticle. Linn. Soc. Symp. Ser. No. 10. Academic Press, London, p. 45-85

Klumpp, D. W., van der Valk, A. (1984). Nutritional quality of seagrasses (Posidonia australis and Heterozostera tasmanica): comparison between species and stages of decomposition. Mar. Biol. Lett. 5: 67-83

Kolattukudy, P. E., Espelie, K. E. (1985). Biosynthesis of cutin, suberin, and associated waxes. In: Higuchi, T (ed.) Biosynthesis and biodegradation of wood components, Chapter 8. Academic Press, London, p. 161-207

Loewus, F. A., Dickinson, D. B. (1981). Cyclitols. In: Lewis, F. A., Tanner, W. (eds.) Plant carbohydrates I. Intracellular carbohydrates. Springer-Verlag, Berlin, p. 193-216

Martin, J. T., Juniper, B. E. (1970). The cuticles of plants. Saint Martin's Press, New York

Meyers-Schulte, K. J., Hedges, J. I. (1986). Molecular evidence for a terrestrial component of organic matter dis-

This article was presented by S. Y. Newell, Sapelo Island, Georgia, USA solved in ocean water. Nature 321.61-63

Moran, M. A., Benner, R., Hodson, R. E. (1989). Kinetics of microbial degradation of vascular plant material in two wetland ecosystems. Oecologia 79: 158-167

Moran, M. A., Hodson, R. E. (1990). Contributions of degrading Spartina alterniflora lignocellulose to the dissolved organic carbon pool of a salt marsh. Mar. Ecol. Prog. Ser. 62: $161-168$

Newell, S. Y., Fell, J. W., Miller, C. (1986). Deposition and decomposition of turtlegrass leaves. Int. Revue ges. Hydrobiol. 71: 363-369

Peduzzi, P., Herndt, G. J. (1991). Decomposition and significance of seagrass litter (Cymodocea nodosa) for the microbial food web in coastal waters (Gulf of Trieste, Northern Adriatic Sea). Mar. Ecol. Prog. Ser. 71: 163-174

Requejo, A. G., Brown, J. S., Boehm, P. D. (1986). Lignin geochemistry of sediments from the Narragansett Bay Estuary. Geochim. Cosmochim. Acta 50: 2707-2717

Robertson, M. L., Mills, A. L., Zieman, J. C. (1982). Microbial synthesis of detritus-like particulates from dissolved organic carbon released by tropical seagrasses. Mar. Ecol. Prog. Ser. 7: 279-285

Rublee, P. A., Roman, M. R. (1982). Decomposition of turtlegrass (Thalassia testudinum Konig) in flowing sea-water tanks and litterbags: compositional changes and comparison with natural particulate matter. J. exp. mar. Biol. Ecol. 58: $47-58$

Sarkanen, K. V., Ludwig, C. H. (1971). Lignins: occurrence, formation, structure, and reactions. Wiley Interscience, New York

Sjöstrom, E. (1981). Wood chemistry, fundamentals and applications. Academic Press, London

Stevenson, J. C. (1988). Comparative ecology of submersed grass beds in freshwater, estuarine, and marine environments. Limnol. Oceanogr. 33: 867-893

Valiela, I., Teal, J. M., Allen, S. D., Van Etten, R., Goehringer, D., Volkman, S. (1985). Decomposition in salt marsh ecosystems: the phases and major factors affecting disappearance of above-ground organic matter J. exp. mar. Biol. Ecol. 89: 29-54

Van Sumere, C. F. (1989). Phenols and phenolic acids. In: Harbourne, J. B. (ed.) Methods in plant biochemistry, Vol. 1. Plant phenolics. Academic Press, London, p. 29-73

Whitehead, D. C., Dibb, H., Hartley, R. D. (1981). Extractant $\mathrm{pH}$ and the release of phenolic compounds from soils, plant roots and leaf litter. Soil Biol. Biochem. 13: 343-348

Wilson, J. O., Buchsbaum, R., Valiella, I., Swain, T (1986). Decomposition in salt marsh ecosystems: phenolic dynamics during decay of litter of Spartina alterniflora. Mar. Ecol. Prog. Ser. 29: 177-187

Wilson, J. O., Valiela, 1. J., Swain, T. (1985). Sources and concentrations of vascular plant material in sediments of Buzzards Bay, Massachusetts, USA. Mar. Biol. 90: 129-137

Wilson, M. A., Verheyen, T V., Vassallo, A. M., Malcolm, R. L. (1987). Selective loss of carbohydrates from plant remains during coalification. Org. Geochem. 11. 265-271

Zapata, O., McMillan, C. (1979). Phenolic acids in seagrasses. Aquat. Bot. $7: 307-317$

Manuscript first received: November 24, 1992

Revised version accepted: February 1, 1993 